\title{
Effects of Benzylaminopurine (BAP) and Naphtalene Acetic Acid (NAA) on Micropropagation of Citrus mitis (Calamansi Lime)
}

\author{
Hasbullah, N.A, Mohammad Mohd Lassim, Patah, F.K.A, Radzuan, N.S., Idris, H., Yusof, M.F. and \\ Amin, M.A.M
}

\begin{abstract}
Experiment was conducted to study the effects of Benzylaminopurine (BAP) and (NAA) on three different types of Citrus mitis explants, leaves, stems and roots. Plant growth regulators combinations were carried out at a concentration $0.0 \mathrm{mg} / \mathrm{l}, 0.5 \mathrm{mg} / \mathrm{l}$, $1.0 \mathrm{mg} / \mathrm{l}, 1.5 \mathrm{mg} / \mathrm{l}$ and $2.0 \mathrm{mg} / \mathrm{l}$. Experiments involved seed sterilization and cultures of explants. These experiments were observed for 2 months where observations and records were taken at week 4 and week 8 . At week 4 , several parameters were observed and recorded such as percentage of callus, number of shoot growth and number of root growth for each explant sample. At week 8 , the parameter was added with weight and size of the callus produced. Results showed that, the stem cultured on the medium containing 1.5 $\mathrm{mg} / \mathrm{l} \mathrm{NAA}+0.5 \mathrm{mg} / \mathrm{l} \mathrm{BAP}$ resulted in optimum callus induction. The stem explant also produced very promising shoot growth. The medium supplemented with $0.5 \mathrm{mg} / \mathrm{l} \mathrm{NAA}+1.0 \mathrm{BAP} \mathrm{mg} / \mathrm{l}$ yielded optimum shoots production. For root growth, leaf explant with combination of $0.5 \mathrm{mg} / \mathrm{l} \mathrm{NAA}+1 \mathrm{mg} / \mathrm{l} \mathrm{BAP}$ and $0.5 \mathrm{mg} / 1 \mathrm{NAA}+1.5 \mathrm{mg} / \mathrm{l} \mathrm{BAP}$ yields optimum roots. Micropropagation of Citrus mitis through tissue culture system was successful.
\end{abstract}

Keywords - micropropagation, Benzylaminopurine, Napthalene Acetic Acid, culture, shoot, callus

\section{INTRODUCTION}

Citrus species are small to medium sized plants which are cultivated throughout the tropic and subtropics. The Citrus

Dr. Nor Azlina Hasbullah1, is with the Department of Agriculture Science, Faculty of Technical and Vocational (FTV), Universiti Pendidikan Sultan Idris (UPSI), Tanjong Malim, Perak, Malaysia.

Prof. Dr. Mohammad Mohd Lassim2, is with the Faculty of Sustainable Agriculture (Sandakan Campus), Universiti Malaysia Sabah (UMS), 90000, Sandakan, Sabah, Malaysia

Fadhlul Khaliq Ab Patah3, is with the Department of Agriculture Science, Faculty of Technical and Vocational (FTV), Universiti Pendidikan Sultan Idris (UPSI), Tanjong Malim, Perak, Malaysia.

Nurul Shifa Radzuan4, is with the Department of Agriculture Science, Faculty of Technical and Vocational (FTV), Universiti Pendidikan Sultan Idris (UPSI), Tanjong Malim, Perak, Malaysia.

Husna Idris5, is with Department of Agriculture Science, Faculty of Technical and Vocational (FTV), Universiti Pendidikan Sultan Idris (UPSI), Tanjong Malim, Perak, Malaysia.

Muhammad Firdaus Yusof6 and Muhamad Azizi Mohamed Amin7, are with the Department of Agriculture Science, Faculty of Technical and Vocational (FTV), Universiti Pendidikan Sultan Idris (UPSI), Tanjong Malim, Perak, Malaysia. family is native to part of India, China, Northern Australia and New Caledonia. All species of Citrus are aboriginal, early European or modern introductions throughout Oceania. The origin of the Calamansi has not been established, but it is believed to potentially have originated in China [1] Citrus mitis or common the name is Calamondin, in Malaysia is known as Limau Kasturi is a very famous edible fruit and has medicinal uses. In other countries, it is known as Calimansi, Panama Orange, Scarlet Lime and Golden Lime based on their structure of fruit or villagers in that country. Citrus mitis is native origin in China [2]. Citrus plant family ais a famous plant in China. In China, all part of Citrus plants are useful for medicine especially their leaves and fruits. Citrus mitis is under Rutaceae family, Magnoliopsida class and the order is Sapindales.

In Malaysia, according to the Malaysian Agriculture Department in Putrajaya, Malaysia [3], Citrus mitis planting area in Peninsular Malaysia is 964.29 hectares yields of 7308.40 $\mathrm{Mt} / \mathrm{year}$. While in Sabah and Sarawak, the planting area is 1034.54 hectares and the yield produced during the year was 7587.16 Mt. Capacity and production of 2015 increased so dramatically in 2011, 776.3 hectares $(4150.53 \mathrm{Mt})$ in the peninsular and 848 hectares (4.461.62 in Sabah and Sarawak). This shows that the Malaysian government help entrepreneurs to expand Citrus mitis planting. It also proves the importance of this crop in the country and its economic growth. Therefore planning and strategies to enhance the crop production needs to be actively done. Besides conventional planting, another alternative to boost the plantation is through plant tissue culture. Tissue culture is also known as in vitro and micropropagation is part of it, based on the protocol of the procedures and the final result of the plant on tissue culture. In vitro refer to the used of the glass jar in the planting of seeds or other part of plant. Cultivation in a glass jar with aseptic technique provides protection to the sources of seeds or other plant parts from the infected organism that can damage plant growth. Through plant cell, tissue and organ culture, mass propagation of the plant species could be obtained. The importance of tissue culture in Citrus research was recognized [10] and amply emphasized by researchers in the field. In vitro propagation on Citrus mitis in this study involved the usage on plant growth regulators to enhance the plant growth. Therefore, in this study, two types of plant growth regulators were used to study their effects on 
micropropagation of the Citrus mitis. A type of cytokinin, Benzylaminopurine and a type of auxin, Napthalene Acetic Acid were used in this study.

\section{MATERIALS AND METHODS}

\section{A. Research Location}

Research and experimental work was done in the Crop Science Lab, Department of Agriculture Science, Faculty of Technical and Vocational, Universiti Pendidikan Sultan Idris (UPSI), Tanjong Malim, Perak, Malaysia.

\section{B. Source of Explants}

Seeds of Citrus mitis were obtained from the supplier and were stored in the refrigerator prior to further experiments. The fruit was cut into two parts and the separation process was carried out. The separation process was done very carefully to avoid damaging the seed.

\section{Explant Preparation and Seed Germination}

Citrus mitis seeds were used as source of seedlings. Excised seeds were sterilized before being cultured onto MS basal medium for seedlings growth (Figure 1a). The seeds were first run under running tap water with the addition of 4 drops of Tween 20 to remove residues and clean the seeds. Next, the seeds were cleaned with $50 \%$ disinfectant for 10 minutes. Subsequently, the seeds were sterilized further using $40 \%$ and $15 \%$ sodium hypochlorite solution for 10 and 15 minutes respectively. Seeds were then rinsed with sterile distilled water for 5 minutes before being placed in the laminar flow cabinet. Seeds were later rinsed with $70 \%$ alcohol for 1 minute and finally rinsed three times with sterile distilled water.

\section{Media and Culture Condition}

Sterilized seeds were cultured on basal MS medium, consisted of nutrients, technical agar, sucrose and the medium $\mathrm{pH}$ was set to 5.8. Cultured seeds were placed in the culture room at $23 \pm 2{ }^{\circ} \mathrm{C}$ with 16 hours light and 8 hours dark photoperiod. 8-week-old plantlets were ready to be used as source of explants for the next experiment.

\section{E. Shoot Regeneration and Callus Induction}

In this study, explants from Citrus mitis plantlets such as shoot, leaf and root explants were used as source of explants. Explants were cultured onto MS medium supplemented with various concentrations of BAP and NAA. The effects of the plant growth regulators supplemented in the culture medium towards the growth of explants were observed. All cultures were incubated in the culture room at $23 \pm 2{ }^{\circ} \mathrm{C}$ with 16 hours light and 8 hours dark photoperiod. Observations were done each week.

\section{F. Statistical Analysis}

Experiments were conducted using Complete Randomized Design (CRD). Results obtained were analyzed using ANOVA with Duncan's Multiple Range Test (DMRT). Each experiment consisted of 30 samples and all experiments were repeated twice.

\section{RESULTS AND DISCUSSION}

All results from the experiments were obtained and recorded. From the three types of explants used in this study, leaf, stem and roots, only stem explants responded well on the organogenesis and micropropagation of Citrus mitis.

\section{A. Effects of Combination of BAP and NAA on Shoot Regeneration}

Shoot regeneration from explants of Citrus mitis was successfully achieved when stem from the aseptic seedlings (Figure 1b) were used as source of explants (Table 1). The highest shoot regeneration was obtained when explants were cultured on MS medium supplemented with $0.5 \mathrm{mg} / \mathrm{l} \mathrm{NAA}+1.0$ $\mathrm{mg} / \mathrm{l} \mathrm{BAP}$ with $4.00 \pm 0.69$ shoots per explant (Figure 2a). Stem explants were also responsive when cultured on MS medium supplemented with $0.5 \mathrm{mg} / 1 \mathrm{NAA}+2.0 \mathrm{mg} / \mathrm{l}$ BAP. Stem explant produced least number of shoots when cultured on MS medium supplemented with $2.0 \mathrm{mg} / \mathrm{l} \mathrm{NAA}+2.0 \mathrm{mg} / \mathrm{l} \mathrm{BAP}$ and $1.5 \mathrm{mg} / \mathrm{l}$ $\mathrm{NAA}+1.5 \mathrm{mg} / \mathrm{l} \mathrm{BAP}$. Control treatment did not respond to shoot regeneration. Explants could not respond when cultured on MS basal medium, without the addition of plant growth regulators. Auxin and Cytokinin are the important regulators of plant growth. Both these hormones are used in the proliferation of explants in tissue culture techniques.

Research on the effect of cytokinin on morphological and biochemical characteristics of the shoots of Citrus in vitro has been made previously [4]. Shoots of citrus plant such as calamondin (Citrus madurensis Lour.) (syn), C. volkameriana, Malta orange (C. sinensis Obseck.), Assam lemon (C. limon Burm.) and Troyer citrange (Poncirns trifoliata X C. sinensis) were cultured on Murashige and Skoog medium (MS) supplemented with benzylaminopurine and kinetin. In the case of Calamondin, $1.25 \mathrm{mg} / \mathrm{l}$ kinetin added in the culture medium resulted highest plant weight. Besides that, BAP at $0.50 \mathrm{mg} / \mathrm{l}$ had produced the maximum number of shoots but the shoot were significantly shorter compare to kinetin treatment. Shoot from the explant of Citrus mitis was successfully achieved using 6- benzylaminopurine [5]. However, the presence of callus is totally different depending on the quantity of 6-benzylaminopurine. This shows that cytokinin is important to enhance the production of shoots in any citrus plant. Nevertheless, cytokinin is also important in sub-culture activities for callus production.

\section{B. Effects of Combination of BAP and NAA on Type of explant on Callus Induction}

Besides shoot regeneration from explants, another observation found in this study was the production of callus from the explants tested. Callus is also another product produced when explants responded to the culture medium and plant growth regulators added in the culture medium. Callus was induced in this study when leaf, stem and root explants were cultured on MS medium supplemented with various concentrations of BAP and NAA. From the experiments, stem explants responded well compared to leaf and root explants to produce callus. At week 8 , highest callus weight produced was when stem explant were cultured on MS medium supplemented with $1.5 \mathrm{mg} / \mathrm{l} \mathrm{NAA}+0.5 \mathrm{mg} / \mathrm{l} \mathrm{BAP}$ with $1.25 \pm 0.08 \mathrm{~g} / \mathrm{explant}$ 
(Table 1, Figure 2b). Medium supplemented with $1.5 \mathrm{mg} / \mathrm{l} \mathrm{NAA}$ $+1.0 \mathrm{mg} / \mathrm{l}$ BAP was also responsive in callus induction. Poor callus induction was observed when stem was cultured on MS medium supplemented with $1.5 \mathrm{mg} / \mathrm{l} \mathrm{NAA}+1.5 \mathrm{mg} / \mathrm{l} \mathrm{BAP}$ with $0.16 \pm 0.01 \mathrm{~g} / \mathrm{explant}$. Explants were non responsive when culture on control treatment, basal MS medium, not added with any plant growth regulators.

Seeds of Citrus mitis can be cultured using MS media and then the resulting explants from the plantlets were cultured using MS media added with the range of 2,4-D and BAP [6]. The reasercher also stated that the higher the combination was applied, the faster growth of callus was obtained. From his research, callus of Citrus mitis was optimum when explants were cultured on $4.0 \mathrm{mg} / \mathrm{l}$ 2,4-D and $1.0 \mathrm{mg} / \mathrm{l} \mathrm{BAP}$. Callus induction of Citrus sinesis was optimum when 2,4-D was added in the culture medium [7]. Meanwhile, the addition of BAP and NAA in the culture medium also significantly affected callus and shoot growth [8]. The result of callus induction in this study is in line with the previous researches whereby the addition of auxin in the culture medium was proven to enhance the callus production.

\section{Effects of Combination of BAP and NAA on Type of explant on Root Formation}

Results from the experiments showed that root formation was observed when stem explants were cultured on the medium tested. However results showed that only 2 medium resulted in the root formation which are MS medium supplemented with $0.5 \mathrm{mg} / \mathrm{l} \mathrm{NAA}+1.0 \mathrm{mg} / \mathrm{l} \mathrm{BAP}$ and MS medium supplemented with $0.5 \mathrm{mg} / \mathrm{l} \mathrm{NAA}+1.0 \mathrm{mg} / \mathrm{l} \mathrm{BAP}$ (Table 1 ). Combinations of cytokinin and auxin in the culture medium were not suitable for formation of roots from explant. Single auxin in the culture medium could enhance root formation from explants [9]
TABLE I:

EFFECTS OF BENZYLAMINOPURINE (BAP) AND NAPTHALENE ACETIC ACID (NAA) ON SHOOT GROWTH, CALLUS WEIGHT AND NUMBER OF ROOTS FROM STEM EXPLANTS OF CITRUS MITIS

\begin{tabular}{|c|c|c|c|}
\hline Treatment & No. of shoot & $\begin{array}{c}\begin{array}{c}\text { Callus } \\
\text { weight (g) }\end{array} \\
\end{array}$ & No. of root \\
\hline MS 0 (Control) & $0.00 \pm 0.00_{\mathrm{g}}$ & $0.00 \pm 0.00_{\mathrm{g}}$ & $0.00 \pm 0.00_{\mathrm{c}}$ \\
\hline $\begin{array}{l}\mathrm{MS}+0.5 \mathrm{mg} / 1 \mathrm{NAA} \\
+1.0 \mathrm{mg} / \mathrm{l} \mathrm{BAP}\end{array}$ & $4.00 \pm 0.69 \mathrm{a}$ & $0.23 \pm 0.04_{f}$ & $0.33 \pm 0.17 \mathrm{a}$ \\
\hline $\begin{array}{l}\mathrm{MS}+0.5 \mathrm{mg} / \mathrm{l} \mathrm{NAA} \\
+1.5 \mathrm{mg} / \mathrm{l} \mathrm{BAP}\end{array}$ & $2.44 \pm 1.06_{c}$ & $0.51 \pm 0.09_{\mathrm{e}}$ & $0.11 \pm 0.11_{\mathrm{b}}$ \\
\hline $\begin{array}{l}\mathrm{MS}+0.5 \mathrm{mg} / \mathrm{l} \mathrm{NAA} \\
+2.0 \mathrm{mg} / \mathrm{l} \mathrm{BAP}\end{array}$ & $3.22 \pm 0.80_{\mathrm{b}}$ & $0.60 \pm 0.08_{d}$ & $0.00 \pm 0.00_{\mathrm{c}}$ \\
\hline $\begin{array}{l}\mathrm{MS}+1.0 \mathrm{mg} / \mathrm{l} \mathrm{NAA} \\
+0.5 \mathrm{mg} / \mathrm{l} \mathrm{BAP}\end{array}$ & $1.10 \pm 0.61_{\mathrm{f}}$ & $0.79 \pm 0.11_{\mathrm{cd}}$ & $0.00 \pm 0.00_{\mathrm{c}}$ \\
\hline $\begin{array}{l}\mathrm{MS}+1.0 \mathrm{mg} / \mathrm{l} \mathrm{NAA} \\
+1.0 \mathrm{mg} / \mathrm{BAP}\end{array}$ & $2.44 \pm 1.24_{c}$ & $0.67 \pm 0.10_{\mathrm{d}}$ & $0.00 \pm 0.00_{c}$ \\
\hline $\begin{array}{l}\mathrm{MS}+1.0 \mathrm{mg} / \mathrm{l} \mathrm{NAA} \\
+1.5 \mathrm{mg} / \mathrm{l} \mathrm{BAP}\end{array}$ & $1.78 \pm 0.89_{\mathrm{e}}$ & $0.71 \pm 0.05_{\mathrm{cd}}$ & $0.00 \pm 0.00_{c}$ \\
\hline $\begin{array}{l}\mathrm{MS}+1.0 \mathrm{mg} / \mathrm{l} \mathrm{NAA} \\
+2.0 \mathrm{mg} / \mathrm{BAP}\end{array}$ & $2.00 \pm 0.90_{\mathrm{e}}$ & $0.50 \pm 0.05_{\mathrm{e}}$ & $0.00 \pm 0.00_{c}$ \\
\hline $\begin{array}{l}\mathrm{MS}+1.5 \mathrm{mg} / \mathrm{l} \mathrm{NAA} \\
+0.5 \mathrm{mg} / \mathrm{BAP}\end{array}$ & $1.11 \pm 0.77_{\mathrm{d}}$ & $1.25 \pm 0.08 \mathrm{a}$ & $0.00 \pm 0.00_{\mathrm{c}}$ \\
\hline $\begin{array}{l}\mathrm{MS}+1.5 \mathrm{mg} / \mathrm{l} \mathrm{NAA} \\
+1.0 \mathrm{mg} / \mathrm{l} \mathrm{BAP}\end{array}$ & $1.44 \pm 0.50_{\mathrm{ef}}$ & $1.00 \pm 0.08 \mathrm{~b}$ & $0.00 \pm 0.00_{c}$ \\
\hline $\begin{array}{l}\mathrm{MS}+1.5 \mathrm{mg} / \mathrm{l} \mathrm{NAA} \\
+1.5 \mathrm{mg} / \mathrm{BAP}\end{array}$ & $1.00 \pm 0.52_{\mathrm{f}}$ & $0.16 \pm 0.01_{\mathrm{f}}$ & $0.00 \pm 0.00_{\mathrm{c}}$ \\
\hline $\begin{array}{l}\mathrm{MS}+1.5 \mathrm{mg} / \mathrm{l} \mathrm{NAA} \\
+2.0 \mathrm{mg} / \mathrm{l} \mathrm{BAP}\end{array}$ & $1.67 \pm 0.65_{\mathrm{fe}}$ & $1.00 \pm 0.07 \mathrm{~b}$ & $0.00 \pm 0.00_{c}$ \\
\hline $\begin{array}{l}\mathrm{MS}+2.0 \mathrm{mg} / \mathrm{l} \mathrm{NAA} \\
+0.5 \mathrm{mg} / \mathrm{BAP}\end{array}$ & $1.33 \pm 0.58_{\mathrm{ef}}$ & $0.91 \pm 0.06_{c}$ & $0.00 \pm 0.00_{c}$ \\
\hline $\begin{array}{l}\mathrm{MS}+2.0 \mathrm{mg} / \mathrm{l} \mathrm{NAA} \\
+1.0 \mathrm{mg} / \mathrm{l} \mathrm{BAP}\end{array}$ & $1.44 \pm 0.71_{\mathrm{ef}}$ & $1.00 \pm 0.04_{b}$ & $0.00 \pm 0.00_{c}$ \\
\hline $\begin{array}{l}\mathrm{MS}+2.0 \mathrm{mg} / \mathrm{l} \mathrm{NAA} \\
+1.5 \mathrm{mg} / \mathrm{BAP}\end{array}$ & $1.11 \pm 0.39_{\mathrm{f}}$ & $0.69 \pm 0.04_{d}$ & $0.00 \pm 0.00_{\mathrm{c}}$ \\
\hline $\begin{array}{l}\mathrm{MS}+2.0 \mathrm{mg} / 1 \mathrm{NAA} \\
+2.0 \mathrm{mg} / 1 \mathrm{BAP}\end{array}$ & $1.00 \pm 0.47_{\mathrm{f}}$ & $0.67 \pm 0.02_{\mathrm{d}}$ & $0.00 \pm 0.00_{\mathrm{c}}$ \\
\hline
\end{tabular}

Mean with different letter in the same column differ significantly at $\mathrm{p}=0.5$ 

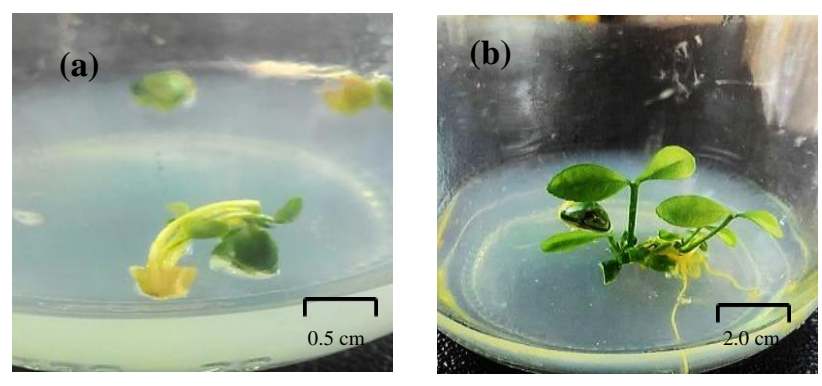

Fig. 1 (a) Germination of Citrus mitis seed (b) Aseptic seedlings of Citrus mitis
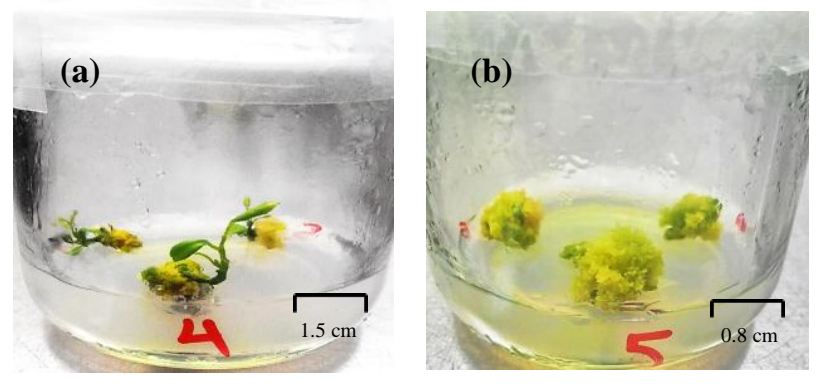

Fig. 2 (a) Shoot produced from stem explant cultured on MS medium supplemented with $0.5 \mathrm{mg} / \mathrm{l} \mathrm{NAA}+1.0 \mathrm{mg} / \mathrm{l} \mathrm{BAP}$ (b) Callus produced from stem explant cultured on MS medium supplemented with $1.5 \mathrm{mg} / \mathrm{l} \mathrm{NAA}+0.5$ $\mathrm{mg} / \mathrm{l} \mathrm{BAP}$

\section{CONCLUSION}

Micropropagation of Citrus mitis was successfully achieved. Through plant tissue culture system, propagation of this plant species could be achieved. Plant growth regulators play important role in inducing and enhancing growth of shoots, callus and roots in vitro. Through this study, mass propagation of Citrus mitis could be achieved apart from the problems paced from conventional planting.

\section{REFERENCES}

[1] Benedict, J., Crowley J., Enocksson, A., and Verdant B. (2014). Philippine Calamansi Association, Inc. Cornal University.

[2] Harley, I.M., Richard, S.B., Verginia, E.S. (2006). Citrus (citrus) and Fortunella (Kumquat), Rutaceae (Rue Family), Species Profile for Pacific Island Agroforestry.

[3] Jabatan pertanian Putrajaya Malaysia (2015). Statistik Tanaman Herba Dan Rempah Ratus.

[4] Parthasarathly, V.A., Anjan Barua, Venketaswarny N. And Utpala Parthasarathy. (2015). Effect of cytokinin on morphological,physiological and biological of shoots of citrus in vitro. Cirad/EDP Sciences. 57(3), 153-160.

[5] Sim, G.E., Goh, C.J. and Loh, C.S. (1989). Micropropagation Of Citrus Mitis Blanco-Multiple Bud Formation From Shoot And Root Explants In The Presence Of 6-Benzylaminopurine. Plant Science. 59, 203-210. https://doi.org/10.1016/0168-9452(89)90138-6

[6] Mahadi, I., Syafi'I, W. and Sari Y. (2016). Induksi Kalus Jeruk Kasturi (Citrus microcarpa) Menggunakan Hormon 2,4-D dan BAP dengan Metode in vitro. Jurnal Ilmu Pertanian Indonesia (JIPI). 21 (2), 84-89. https://doi.org/10.18343/jipi.21.2.84

[7] Azim, F., Ramham, M.M., Shamsul, H.P., Saif, U.S., Nayem Z. and Ashrafuzzaman (2011). Development Of Efficient Callus Initiation Of Malta (Citrus sinensis) Through Tissue Culture. International Journal of Agricultural Research Innovation \& Technology. 12, 64-68).

[8] Sharma, H. (2017). Growth Regulators in Micropropogation of Woody Olants. International Journal of Advanced Reserche. 5(2), 2378-2385. https://doi.org/10.21474/IJAR01/3421
[9] Adhikarimayum H., Kshetrimayum G., Huidrom S. and Maibam D. (2011). In vitro propagation of Citrus megaloxycarpa. Environmental and Experimental Biology. 9, 129-132.

[10] Singh, I.P. (2012). Micropropagation In Citrus - A Review. National research centre for citrus, India. 23(1), 1-13. 